\title{
The Place and Role of International Human Rights Law in the EU Return Directive and in the Related CJEU Case-Law: Approaches Worlds Apart?
}

\author{
Dr Tamás Molnár
}

\subsection{Introduction}

This contribution deals with the interactions of two functionally differentiated legal orders, i.e. supranational law (European Union (EU) law) and international human rights law, from the perspective of EU law, in a particular field of law: the expulsion/return of irregular migrants. More specifically, it examines the place and role of international human rights law in the EUReturn Directive (Directive $2008 / 115 / E C),{ }^{1}$ which is the key EU law instrument relating to the return of migrants in an irregular situation (this field of law is called the "expulsion of aliens" in the UN International Law Commission's parlance $)^{2}$ and in the return related case-law of the Court of Justice of the EU (CJEU).

It aims at comparing and understanding the different approaches of the $E U$ legislature (as manifested in the text of the Return Directive) and the EUjudiciary, which is the guardian that the "law is observed" in the interpretation and application of the EU Treaties (Article 19(1) of the Treaty on European Union $(\mathrm{TEU})$ ), towards international human rights law in the context of EU return law and policy. Examining these different approaches more horizontally, some leading scholars argued: "[g]iven their differing functions, a comparison of how the [EU] Court and the EU legislature deal with international law may at first glance seem to provide only limited insight. However, such a comparison is warranted, especially given the new post-Lisbon text of the Treaties containing a number of references to international law, the growing convergence between

1 Directive 2008/115/EC of the European Parliament and of the Council of 16 December 2008 on common standards and procedures in Member States for returning illegally staying thirdcountry nationals, OJ L 348, 12.24.2008, pp.188-197.

2 See: Expulsion of aliens - Text of the draft articles and commentaries thereto, Report of the International Law Commission, Sixty-sixth session, GAOR, 69th session, Supp. No 10, A/69/10 (2014). 
regulatory efforts on the international and European levels, as well as recent case law of the [EU] Court that demonstrates a more reticent attitude towards international law". (Wouters, Odermatt and Ramopoulos, 2012). I could not but fully agree with them and I attempt to carry out a similar exercise in a more targeted way, zooming in on one specific field of law.

This short piece first looks at the specific interactions between EU law and international law in the field of migration, covering both the dynamics between these legal normative layers and the relevance of international law for EU migration/asylum law-making (Section 2). It follows by outlining the role and place of international human rights law in the Return Directive (Section 3 ) and in the CJEU case-law respectively (Section 4), before phrasing some conclusions based on this comparison (Section 5 ).

\subsection{Specific Interactions Between EU Law and International Law in Field of Migration}

\subsubsection{Dynamics between EU Law and the International Legal Order}

Since the Treaty of Maastricht (1992), EU law became more open to international law and engaged with it in different forms of interactions. It is not just that international law has traditionally been part and parcel of EU law as pointed out by CJEU rulings in Haegeman, ${ }^{3}$ Poulsen ${ }^{4}$ or Opel Austria. ${ }^{5}$ Also, the international treaty-making activity of the Union has been constantly increasing (see e.g. the European External Action Service database on international treaties to which the Union is a party). ${ }^{6}$ Similarly, both EU primary law and secondary legislation have become considerably open to and have oftentimes been inspired by international law. The Treaty of Lisbon, entered into force on 1 December 2009, is evident in this regard. For instance, Article 3(5) TEU ${ }^{7}$ stipulates for the first time in primary Union law that "[i]n its relations with the wider world, the Union shall $[\ldots]$ contribute $[\ldots]$ to the strict observance and the development of international law, including respect for the principles of the United Nations

3 CJEU, Case 181-73, R. \& V. Haegeman v. Belgian State, Judgment of 30 April 1974, ECLI:EU:C:1974:41.

4 CJEu, Case C-286/9o, Anklagemyndigheden v. Peter Michael Poulsen and Diva Navigation Corp., Judgment of 24 November 1992, ECLI:EU:C:1992:453.

5 CJEU, Case T-115/94, Opel Austria GmbH v. Council of the European Union, Judgment of the Court of First Instance (Fourth Chamber) of 22 January 1997, ECLI:EU:T:1997:3.

6 See http://ec.europa.eu/world/agreements/viewCollection.do.

7 For a commentary on Article 3(5) TEU, consider e.g. Blanke and Mangiameli (2013), pp. 17918 o. 
Charter". This obligation is complemented by Article 21( $(1) T E U$ : "Union's action on the international scene shall be guided by $[\ldots]$ the principles which have inspired its own creation, [including the] respect for the principles of the United Nations Charter and international law". What is more, in pursuing this general objective, the EU shall "consolidate and support [...] the principles of international law" as ordered by the Article 21(2) TEU.

More specifically, EU migration and asylum acquis, which is a relatively new policy field ("communitarised" in May 1999 with the entry into force of the Treaty of Amsterdam), has always been drawing on a lot or has been largely inspired by pre-existing international migration law and human rights law. Nevertheless, it is yet a largely unexplored issue how EU migration law relates to international law (Maes, Vanheule, Wouters and Foblets, 2011). As Steve Peers put it, "[t]he development of immigration and asylum law within [....] the European Union $(E U)[\ldots]$ necessarily takes place within an international framework, since it principally concerns the regulation of foreign nationals moving to and from foreign countries". (Peers, 2011). It is worth noting that major universal treaties on migration ${ }^{8}$ and refugee law $^{9}$ as well as the European Convention on Human Rights (ECHR) and core UN human rights conventions relevant for the rights of migrants ${ }^{10}$ had already been adopted before the EU has appeared on this scene as law-maker. Arguably, it was in the interests of the European integration project to rely on those previously elaborated and more or less settled norms and standards which have been endorsed and followed by the Member States, and which served as obvious sources of inspiration and starting points for the EU own standard setting activities.

The influence of external legal norms on the EU migration and asylum acquis has been twofold. On the one hand, some of them have surfaced explicitly, as in case of the $195^{1}$ Geneva Convention relating to the Status of Refugees and

8 E.g. 2000 Protocol against the Smuggling of Migrants by Land, Sea and Air supplementing the United Nations Convention against Transnational Organized Crime (UNTS No. 39574, vol. 2241, p. 507) and the 2000 Protocol to Prevent, Suppress and Punish Trafficking in Persons Especially Women and Children, supplementing the United Nations Convention against Transnational Organized Crime (No. 39574, vol. 2237, p. 319).

91951 Convention Relating to the Status of Refugees (UNTS No. 2545, vol. 189, p. 137) and ${ }_{1967}$ Protocol Relating to the Status of Refugees (UNTS No. 8791, vol. 6o6, p. 267).

10 For instance, the 1966 International Covenant on Civil and Political Rights (UNTS No. 14668, vol. 999, p. 171); the 1966 International Covenant on Social, Economic and Cultural Rights (UNTS No. 14531, vol. 993, p. 3); the 1984 Convention against Torture and Other Cruel, Inhuman or Degrading Treatment or Punishment (UNTS No. 24841, vol. 1465, p. 85); the 1989 Convention on the Rights of the Child (UNTS No. 27531, vol. 1577, p. 3) or the 199o International Convention on the Protection of the Rights of All Migrant Workers and Members of Their Families (UNTS, No. vol. 2220, p. 3). 
its 1967 New York Protocol. The first mention of the former in the founding Treaties has been inserted by the Treaty of Maastricht, ${ }^{11}$ while the latter has appeared first in the Treaty of Amsterdam ${ }^{12}$ and now they both appear in the "Lisbonised" version of the Treaty on the functioning of the European Union (TFEU) ${ }^{13}$

On the other hand, a number of external human rights standards had an implicit influence on EU migration law, via the infiltration of internationally protected human rights which are of particular significance for foreigners. The concept of the "general principles of EU law" provided a legal channel for the latter, of which fundamental rights form an integral part. ${ }^{14}$ Another technique, applied by the EU legislature, is to insert "without prejudice" or "non-affectation clauses" in secondary EU legislation and EU-agreements (e.g. readmission agreements) in order to give priority to the application of certain human rights conventions over EU migration/asylum law.

Finally, it is widely known that those fundamental rights enshrined in the EU Charter of Fundamental Rights ("EU Charter") which are applicable to migrants, irrespective of their nationality and migration status (irregular or lawfully staying), have drawn from various international human rights and refugee law instruments (consider e.g. Article 4 on the prohibition of torture and other forms of ill-treatment, Article 18 on the right to asylum or Article 19 on the prohibition of collective expulsions and non-refoulement). As a leading authority in this field put it, "[e]ven a cursory look at the Charter [...] will reveal that it draws upon [....] a number of international human rights instruments. Such instruments, in fact, have influenced [...] the preparation and drafting of the Charter, and this despite the fact that the $E U$, with one recent

11 In ex Article K.2(1) of the original version of the Treaty on European Union.

12 In ex-Article 63(1) of the Treaty establishing the European Community

13 OJ C 326, 26.10.2012, pp. 47-39o. Article 78 TFEU stipulates that the "Union shall develop a common policy on asylum, subsidiary protection and temporary protection [...] This policy must be in accordance with the Geneva Convention of 28 July $195^{1}$ and the Protocol of 31 January 1967 relating to the status of refugees, and other relevant treaties". This formulation of the relevant international obligations (introduced by the Treaty of Maastricht, then expanded by the Treaty of Amsterdam), which indicates the international legal boundaries of EU norms on asylum, goes beyond the two principal instruments of international refugee law, since it makes reference to "other relevant treaties", too (e.g. the 1984 UN Convention against Torture).

14 The leading case in this respect is CJEU, Case 11-70, International Handelsgesellschaft v. Einfuhr- und Vorratsstelle Getreide, Judgment of the Court of 17 December 1970, ECLI:EU:C:1970:114. With respect to the ECHR as a source of general principles of law, see also Article 6(3) TEU. 
exception, ${ }^{15}$ is not a contracting party to any international human rights treaty" (Rosas, 2014).

\subsubsection{Relevance of International (Human Rights) Law for EU Return Law and Policy}

The EU emerging return acquis (i.e. the law and policy dealing with the repatriation of "illegally staying third country nationals"), ${ }^{16}$ which has been occupying more and more legal space since the early 20oos, represents a regulatory field where the infiltration of internationally protected human rights, notably those with particular significance for foreigners, is tangible as an implicit form of the above normative influence. It is corroborated by explicit references to instruments of international human rights law in secondary EU legislation related to the return of irregular migrants, notably but not exclusively the Return Directive (see in section 3). Regarding the possible sources of the fundamental rights protected by and within the EU legal order, including those applicable to migrants in an irregular situation, the CJEU stipulated long ago: "international treaties for the protection of human rights on which the member states have collaborated or of which they are signatories, can supply guidelines which should be followed within the framework of Community law". ${ }^{17}$ This legal technique has been later confirmed in primary EU law, ever since the Treaty of Maastricht, in respect of the ECHR (and its Protocols ratified by all EU Member States, I would add), qualifying fundamental rights guaranteed by the ECHR as general principles of EU law. ${ }^{18}$

In the return context, the relevant international treaties include first and foremost the 1950 European Convention on Human Rights, most importantly its Article 3 (prohibition of torture or other degrading or inhuman treatment,

15 The EU is a party to the UN Convention on the Rights of Persons with Disabilities (adopted on 13 December 2006, UNTS No. 44910, vol. 2515, p. 3). The EU acceded to the convention by Council Decision 2010/48/EC (OJ L 23, 27.1.2010, pp. 35-61), which entered into force for the EU on 23 December 2010.

16 This is the official terminology used by the EU Return Directive (see Articles 1 and 3) for those non-EU nationals who are found in the EU in an irregular situation, and who must be issued a return decision (Article 6(1)).

17 First pronounced in Case 4/73, J. Nold, Kohlen- und Baustoffgroßhandlung v. Commission of the European Communities, Judgment of the Court of 14 May 1974, ECLI:EU:C:1974:51. In subsequent jurisprudence, see e.g. Case 44/79, Hauer v. Land Rheinland Pfalz, Judgment of the Court of 13 December 1979, ECLI:EU:C:1979:29o; or Case C-36/o2, Omega, Judgment of the Court of 14 October 2004, ECLI:EU:C:2004:614, para. 35 .

18 Article 6 (3) TEU: "Fundamental rights, as guaranteed by the European Convention for the Protection of Human Rights and Fundamental Freedoms, [... .] shall constitute general principles of the Union's law". For more on this, see e.g. Tomuschat, 2016. 
enshrining an implied non-refoulement obligation). As per the protocols to the ECHR, Protocol No. 4 lays down the prohibition of expulsion of nationals and the prohibition of collective expulsion of aliens, ${ }^{19}$ while Protocol No. 7 contains various procedural safeguards relating to the expulsion of aliens, which have been interpreted and detailed in the case-law of the European Court of Human Rights (Е СTHR). ${ }^{20}$ Likewise, the 1966 International Covenant on Civil and Political Rights (ICCPR) is also a relevant treaty source of fundamental rights within the Union as general principles of law, being a convention to which all EU Member States are parties. Specifically, it is Article 13 of the ICCPR that deals with the modalities of expelling lawfully staying aliens, as interpreted by the general comments and the quasi-jurisprudence of its treaty-body, the Human Rights Committee (HRC). ${ }^{21}$ The 1984 Convention Against Torture (САT) is a similar international treaty source of inspiration, ratified by all EU Member States, which expressly sets out the universally accepted obligation of non-refoulement (Article 3), protecting any person present under a State's jurisdiction from refoulement. This explicit prohibition, coupled with Articles 6-7 of the ICC PR as interpreted by the HRC, has made non-refoulement an integral component of the prohibition of torture and cruel, inhuman or degrading treatment or punishment, having now the rank of general customary international law (Lauterpacht and Bethlehem, 2003; Goodwin-Gill and McAdam, 2007; Costello and Foster, 2016). Other universally ratified treaties can also be mentioned, such as the 1989 Convention on the Rights of the Child (CRC), enshrining, amongst others, a cornerstone and overarching child protection principle, the best interests of the child (Article 3). This principle must be a primary consideration in all actions concerning children undertaken by public authorities or private institutions; including return related procedures.

In light of the above, the corpus of "internally applicable" (i.e. with the EU legal order) external human rights norms include, inter alia, the principle of non-refoulement, the prohibition of collective expulsion, various procedural safeguards in case of expulsion as well as the best interests of the child. These are complemented by the right to respect for family life under the CRC and the

19 For more on the key concepts of the Strasbourg jurisprudence on this prohibited practice, see European Court of Human Rights (Directorate of the Jurisconsult), Guide on Article 4 of Protocol No. 4 to the European Convention on Human Rights. Prohibition of collective expulsions of aliens, updated on 30 April 2017, available at http://www.echr.coe.int/Documents/Guide_Art_4_Protocol_4_ENG.pdf. related adjudication of the Strasbourg Court, consider Farahat (2015).

21 On the HRC case-law relating to Article 13 ICCPR, see in detail e.g. Wojnowska-Radzińska (2015). 
ECHR; the non-arbitrariness and proportionality of detention (pursuant to the ICCPR, the CRC and the ECHR), and the need to ensure humane and dignified detention conditions (stemming from the standards of the UN Working Group on Arbitrary Detention, ${ }^{22}$ the European Committee for the Prevention of Torture and Inhuman or Degrading Treatment or Punishment (CPT) ${ }^{23}$ and other Council of Europe soft law instruments). ${ }^{24}$

\subsection{The EU Return Directive and International (Human Rights) Law}

In contrast to primary EU law provisions on asylum (Article 78(1) of the TFEU and Article 18 of the EU Charter), the TFEU legal base for common immigration law and policy (Article 79) does not specify that secondary EU legislation must be compatible with certain international treaties. However, the absence of an explicit reference to international law in the founding Treaties in connection with Union policies governing irregular migration does not prevent incorporating such clauses in the legal acts adopted by EU institutions, especially in the mirrors of the aforementioned firm embeddedness of EU migration law in international human rights law (Hailbronner and Thym, 2016).

The keystone legal instrument of the Union's return policy, the EU Return Directive (Directive 2008/115/EC), which entered into force in January 2009, refers quite a few times to international human rights law in general and as embodied in specific treaties. The Return Directive attributes different roles to internationally protected human rights in its scope of application, which can be summarised as follows:

- conceiving them as standards of conformity for EU law (see recitals (17), (22)-(24) and Articles 1, 5);

- providing them priority vis-à-vis EU law (Articles 5 and 9); and

- applying "without prejudice" or "non-affectation" clauses, which make the application of international human rights treaties possible where these rules lay down more favourable conditions for the irregular migrant subject to a return procedure (recital (23) and Article 4(1)).

22 UN Human Rights Council, Report of the Working Group on Arbitrary Detention, A/HRC/ 13/30, 18 January 2010, paras. 54-65.

23 Council of Europe's Committee for the Prevention of Torture and Inhuman or Degrading Treatment or Punishment, Safeguards for irregular migrants deprived of their liberty, Extract from the 19th General Report of the CPT, CPT/Inf(2009)27-part.

24 Twenty Guidelines of the Committee of Ministers of the Council of Europe on Forced Return, adopted at the 925th Meeting of the Ministers' Deputies, Strasbourg, 4 May 2005. 
The below table (Table 4.1) provides an overview of these secondary EU law provisions opening up towards international human rights standards and norms, be them universal or regional ones.

As shown above, the international human rights conventions which serve as yardsticks to assess the legality of the application of the Directive include the 1950 European Convention on Human Rights, the 1951 Geneva Convention relating to the Status of Refugees and its 1967 New York Protocol, the 1989 Convention on the Rights of the Child, coupled with all other relevant treaties concluded by the Member States, the European Union or both, which contain more favourable provisions (e.g. CoE Istanbul Convention on combatting violence against women and domestic violence; ${ }^{25}$ or the CoE Warsaw Convention against Trafficking in Human Beings). ${ }^{26}$

Content-wise, besides general references to "international law", "refugee protection" and "fundamental rights/human rights obligations", the operative provisions name a few concrete international human rights norms and principles such as the best interests of the child, the right to family life, the principle of non-refoulement, the principle to provide humane and dignified detention conditions and to respect dignity and psychical integrity of the irregular migrants.

Some other provisions have been clearly inspired by CoE human rights standards and mirror their language. For instance, Articles 16-17 of the Return Directive on detention conditions are a good illustration for that, which have been largely based on the CoE 20 Guidelines on Forced Return ${ }^{27}$ (EU Return Handbook, 2017). Similarly, Article 13(1) of the Return Directive on the right to an effective remedy against return related decisions is closely modelled after the same guidelines on forced returns (CoE Guideline 5.1) and it should be interpreted in accordance with relevant ECtHR case-law as stipulated in the EU Return Handbook. ${ }^{28}$

25 Council of Europe Convention on preventing and combating violence against women and domestic violence, Istanbul, 11 May 2011 (CETS No. 2010), Articles 59 and 61. The EU signed this convention in June 2017, ratification will follow soon. Council of Europe Convention on Action against Trafficking in Human Beings, Warsaw, 16 May 2005 (CETS No. 197), Article 13 - no expulsion during the recovery and reflection period of at least 30 days.

27 Twenty Guidelines of the Committee of Ministers of the Council of Europe on Forced Return, adopted at the 925th Meeting of the Ministers' Deputies, Strasbourg, 4 May 2005, available at https://www.coe.int/t/dg3/migration/archives/Source/MalagaRegConf/2O_ Guidelines_Forced_Return_en.pdf. 
TABLE 4.1 References to international (human rights) law in the Return Directive

Recital (3) "On 4 May 2005, the Committee of Ministers of the Council of Europe adopted 'Twenty guidelines on forced return'".

Recital (17) "Third-country nationals in detention should be treated in a humane and dignified manner with respect for their fundamental rights and in compliance with international [...] law".

Recital (22) "In line with the 1989 United Nations Convention on the Rights of the Child, the 'best interests of the child' should be a primary consideration of Member States when implementing this Directive. In line with the European Convention for the Protection of Human Rights and Fundamental Freedoms, respect for family life should be a primary consideration of Member States when implementing this Directive".

Recital (23) "Application of this Directive is without prejudice to the obligations resulting from the Geneva Convention relating to the Status of Refugees of 28 July 1951, as amended by the New York Protocol of 31 January 1967".

Recital (24) "This Directive respects the fundamental rights and observes the principles recognised in particular by the Charter of Fundamental Rights of the European Union".

Article 1 "This Directive sets out common standards and procedures to be applied in Member States for returning illegally staying third-country nationals, in accordance with fundamental rights as general principles of Community law as well as international law, including refugee protection and human rights obligations".

Article 4 (1) "This Directive shall be without prejudice to more favourable provisions of:

(a) bilateral or multilateral agreements between the Community or the Community and its Member States and one or more third countries;

(b) bilateral or multilateral agreements between one or more Member States and one or more third countries". 
TABLE 4.1 Continued

Recital (3) "On 4 May 20o5, the Committee of Ministers of the
Council of Europe adopted 'Twenty guidelines on forced
return'".
"When implementing this Directive, Member States shall
take due account of:
Article 5
(a) the best interest of the child;
(b) family life;
(c) the state of health of the third country national
and respect the principle of non-refoulement".
"1. Member States shall postpone removal:
(a) when it would violate the principles of non-
Article 9
2. Mefoulement, [... $]$
appropriate period taking into account the specific
circumstances of the individual case. Member States
shall in particular take into account:
(a) the third-country national's physical state or mental
capacity;"
"The best interests of the child shall be a primary
consideration in the context of the detention of minors
pending removal".

What is more, the EU Return Handbook, which essentially deals with standards and procedures in Member States for returning irregular migrants and is based on EU legal instruments regulating this issue (in particular the Return Directive), contains further references to international human rights law relevant for migrants. This Handbook provides guidance relating to the performance of duties of Member States' authorities competent for carrying out return related tasks. It specifies that in relation to the detention of children and families, $C P T$ standards must be applied beyond the text of the Directive. Similarly, in case of non-removable irregular migrants, be it due to legal or humanitarian impediments, practical obstacles or policy choices, access to education for children as laid down in the Return Directive (Article 14(1)(c)) should be provided in accordance with the $C R C$ and General Comment No. 6 (2005) of the Committee on the Rights of the Child relating to the treatment 
of unaccompanied and separated children in the context of migration ${ }^{29}$ (EU Return Handbook, 2017).

Such provisions as well as the travaux preparatoires of the Directive (Lutz, 2010) showcase that the EU co-legislators (the Council and the Parliament), but also the Commission (see the Return Handbook) had a vision of a fairly international law friendly approach when codifying the common EU standards and procedures for returning irregularly staying third-country nationals. Accordingly, compliance with fundamental rights, which comprise norms laid down in international human rights instruments, is meant to be a cardinal principle of interpretation of the Return Directive (cf. Lutz and Mananashvili, 2016). In the following section, we will see to what extent the EU Court of Justice developed its case-law on returns in line with the legislature's openness to international human rights law.

\subsection{The CJEU Jurisprudence on the Return Directive and International (Human Rights) Law}

The CJEU is playing an ever-important role in the development of European return law since its initial ruling on this matter in Kadzoev in November 20o9. ${ }^{30}$ The CJEU's jurisdiction to rule in preliminary references as well as in other actions has a substantial impact on the definitional and interpretative guidance of EU legislation on returning irregular migrants (Taylor, 2015). Judgments of the EU Court are all the more instrumental given that as described before, written EU law makes explicit reference to international treaties and human rights law. Putting the evolution within the EU law and international law duality under scrutiny in light of this case-law in order to see where it is developing in times of large scale migratory movements is particularly worthy of academic attention.

Looking carefully at the CJEU's case-law in this domain, one can notice a rather EU-law centred argumentative strategy, without genuinely engaging with applicable international human rights law standards, including the ECHR and relevant ECtHR judgments. In contrast to the Völkerrechtsfreundlichkeit advanced by the EU legislator, as depicted above, the Court of Justice of the EU has been rather reluctant so far to refer to international human rights law when

29 UN Committee on the Rights of the Child (CRC), General comment No. 6 (2005): Treatment of Unaccompanied and Separated Children Outside their Country of Origin, 1 September 2005, CRC/GC/2005/6, available at: http://www.refworld.org/docid/42dd174b4.html. 
interpreting the Return Directive. Despite the CJEU's expanding case-law relating to the Directive (2o rulings since the 2009 Kadzoev and three cases are currently pending - see Tables 4.2 and 4.3 below), the EU judiciary seemed, up to now, to be unwilling to step out of the EU law framework when shaping its case-law on returns - in spite of some suggestions from the Advocate Generals.

After reading carefully the above rulings, one can conclude that the CJEU has only sporadically referred to international (human rights) law when interpreting different provisions of the Return Directive. First and foremost, such a source of international origin relied on by the Court is the European Convention of Human Rights as interpreted by the ECtHR. True, this is a clearly set duty of the CJEU under the Charter (Article 52(3)) to duly take into account the ECtHR case-law when interpreting Charter rights corresponding to those laid down in the ECHR. Furthermore, as Mananashvili and De Bruycker rightly observed, "[t]he obligation of the Court and the Advocate General to consult the relevant Strasbourg case law derives in first place from Article 1 of the [Return Directive]", which lays down that the Directive must be applied "in accordance with fundamental rights as general principles of [EU] law as well as international law, including refugee protection and human rights obligations". (De Bruycker and Mananashvili, 2015). References to the ECHR and the ECtHR case-law vary from acknowledging States' sovereign powers to decide on admitting and expelling non-nationals (see the Advocate General's Opinion in Kadzoev ${ }^{31}$ and in El Dridi), ${ }^{32}$ through applying the ECtHR's proportionality test in the context of the length of immigration detention (see the El Dridi judgment), ${ }^{33}$ to interpreting the principle of non-refoulement as set out in Article 19(2) of the Charter in respect of serious health issues in accordance with the Strasbourg jurisprudence (see the Abdida ruling). ${ }^{34}$ In addition, the Council of Europe 20 Guidelines on Forced Return have been mentioned and used on one occasion as a general standard of conformity for national law to comply with EU law as well (see the El Dridi judgment). ${ }^{35}$ In other words, CoE Guideline no. 8 has been considered as an interpretative tool which fills in with normative content certain terms of the Return Directive on the length of pre-removal detention and also to define their concrete meaning to which Member States' legislation must conform with.

\begin{tabular}{ll}
\hline 31 & Para. 5 \\
32 & Para. 29. \\
33 & Paras. 43-44. \\
34 & Paras. 47, 51-52. \\
35 & Paras. $43^{-44 .}$
\end{tabular}


TABLE 4.2 list of CJEU judgments relating to the Return Directive (as of 15.04.2018)

\begin{tabular}{|c|c|c|}
\hline Case & Date & Subject-matter \\
\hline Kadzoev $(C-$ & Judgment of 30 & detention - reasons for \\
\hline 357/og $P P U)$ & November 2009 & prolongation; link to asylum \\
\hline ECLI:EU:C:2009:741 & & related detention \\
\hline El Dridi $(C-61 / 11 P P U)$ & Judgment of 28 April & criminalisation - penalisation \\
\hline ECLI:EU:C:2011:268 & 2011 & of illegal stay by imprisonment \\
\hline Achughbabian (C-329) & Judgment of 6 & criminalisation - penalisation \\
\hline 11) ECLI:EU:C:2011:807 & December 2011 & of illegal stay by imprisonment \\
\hline Sagor $(C-430 / 11)$ & Judgment of 6 & criminalisation - penalisation \\
\hline ECLI:EU:C:2012:777 & December 2012 & $\begin{array}{l}\text { of illegal stay by fine; } \\
\text { expulsion order; house arrest }\end{array}$ \\
\hline Mbaye $(C-522 / 11)$ & Order of 21 March & criminalisation of illegal stay \\
\hline ECLI:EU:C:2013:19o & 2013 & \\
\hline Arslan $\left(C_{-534 / 11)}\right.$ & Judgment of 30 May & return or asylum related \\
\hline ECLI:EU:C:2013:343 & 2013 & detention \\
\hline G. and $R .(C-$ & Judgment of 10 & right to be heard before \\
\hline 383/13 PPU) & September 2013 & prolonging detention \\
\hline \multicolumn{3}{|l|}{ ECLI:EU:C:2013:533 } \\
\hline Filev and Osmani & Judgment of 19 & entry bans - need to \\
\hline$(C-297 / 12)$ & September 2013 & determine ex officio length; \\
\hline ECLI:EU:C:2013:569 & & historic entry bans \\
\hline $\operatorname{Mahdi}(C-146 / 14 P P U)$ & Judgment of 5 June & detention - reasons for \\
\hline ECLI:EU:C:2014:1320 & 2014 & $\begin{array}{l}\text { prolongation and judicial } \\
\text { supervision }\end{array}$ \\
\hline Da Silva $(C-189 / 13)$ & Judgment of 3 July & criminalisation - illegal entry \\
\hline ECLI:EU:C:2014:2043 & 2014 & \\
\hline $\operatorname{Bero}(C-473 / 13)$ and & Judgment of 17 July & detention conditions - \\
\hline Bouzalmate $(C-514 / 13)$ & 2014 & obligation to provide for \\
\hline ECLI:EU:C:2014:2095 & & specialised facilities \\
\hline $\operatorname{Pham}(C-474 / 13)$ & Judgment of 17 July & detention conditions - not at \\
\hline ECLI:EU:C:2014:2096 & 2014 & disposal of detainee to choose \\
\hline Mukarubega & Judgment of 6 & right to be heard before issuing \\
\hline$(C-166 / 13)$ & November 2014 & a return decision \\
\hline ECLI:EU:C:2014:23 & & \\
\hline
\end{tabular}




\begin{tabular}{|c|c|c|}
\hline Case & Date & Subject-matter \\
\hline Boudjlida $(C-249 / 13)$ & Judgment of 11 & right to be heard before issuing \\
\hline ECLI:EU:C:2014:2431 & December 2014 & a return decision \\
\hline Abdida $(C-562 / 13)$ & Judgment of 18 & rights pending postponed \\
\hline ECLI:EU:C:2014:2453 & December 2014 & return \\
\hline Zaizoune $(C-38 / 14)$ & Judgment of 23 April & obligation to issue return \\
\hline ECLI:EU:C:2015:26o & 2015 & decision \\
\hline Zh. \& O. $(C-554 / 13)$ & Judgment of 11 June & risk to public policy \\
\hline ECLI:EU:C:2015:94 & 2015 & \\
\hline Celaj $(C-290 / 14)$ & Judgment of 1 & prison sanction, entry ban and \\
\hline ECLI:EU:C:2015:640 & October 2015 & removal \\
\hline Affum $(C-47 / 15)$ & Judgment of 7 June & transit passenger and illegal \\
\hline ECLI:EU:C:2016:408 & 2016 & stay \\
\hline Ouhrami $(C-225 / 16)$ & Judgment of 26 July & starting point of the duration \\
\hline ECLI:EU:C:2017:590 & 2017 & of an entry ban \\
\hline$E(C-240 / 17)$ & Judgment of 16 & return decision, entry ban, and \\
\hline ECLI:EU:C:2018:8 & January 2018 & $\begin{array}{l}\text { consultations with another } \\
\text { Member States having issued a } \\
\text { residence permit }\end{array}$ \\
\hline
\end{tabular}

SOURCE: LUTZ AND MANANASHVILI [2016]; CMR QUARTERLY OVERVIEW OF CJEU JUDGMENT AND PENDING CASES (MARCH 2018)

Certainly, not each and every case offers a stepping stone for the EU Court to engage more with international human rights law. It depends on the subjectmatter of the individual case, and is limited by the (narrow) questions the referring national court may ask. Nevertheless, cases seeking the interpretation of procedural safeguards such as the right to be heard and the right to an effective judicial review of detention; or those relating to detention conditions could have provided more room for using international human rights norms at least as interpretative tools. Some of the pending cases are promising in this respect, which figure in the below table (Table 4.3) portraying all cases in the Court's docket at the time when the manuscript was submitted.

One of them concerns the implications of the right to family life in connection with the issuance of a return decision and the suspension of an entry ban (K.A. and Others), whereas two other cases touch upon the issue of suspensive 
TABLE 4.3 list of Return Directive-related cases pending before the CJEU (as of 15.04.2018)

\begin{tabular}{|c|c|c|}
\hline Case & Action & Subject-matter \\
\hline K.A. and Others & $\begin{array}{l}\text { Opinion of the Advocate } \\
\text { General (26 October 2017) }\end{array}$ & $\begin{array}{l}\text { suspension of entry ban } \\
\text { and family life }\end{array}$ \\
\hline$(\mathrm{C}-82 / 16)$ & ECLI:EU:C:2017:821 & \\
\hline Xv. Belastingdienst/ & Opinion of the Advocate & suspensive effect \\
\hline Toeslagen (C-175/17) & $\begin{array}{l}\text { General (24 January 2018) } \\
\text { ECLI:EU:C:2018:34 }\end{array}$ & $\begin{array}{l}\text { of appeal (risk of } \\
\text { refoulement) }\end{array}$ \\
\hline Gnandi & $\begin{array}{l}\text { Opinion of the Advocate } \\
\text { General (22 February 2018) }\end{array}$ & $\begin{array}{l}\text { suspensive effect and } \\
\text { effective remedy }\end{array}$ \\
\hline$(\mathrm{C}-181 / 16)$ & ECLI:EU:C:2018:90 & \\
\hline Arib and Others & $\begin{array}{l}\text { Application (15 September } \\
2017)\end{array}$ & $\begin{array}{l}\text { penal sanctions on } \\
\text { illegal entry after }\end{array}$ \\
\hline$(\mathrm{C}-444 / 17)$ & OJ 2008 L 348, p. 98 & $\begin{array}{l}\text { reintroduced border } \\
\text { controls }\end{array}$ \\
\hline
\end{tabular}

effect of appeals against return decisions in light of the right to effective judicial remedy and in the context of non-refoulement claims (Gnandi, and Xv. Belastingdienst/Toeslagen, respectively).

Mapping and analysing the CJEU's above practice allowed to explore the possible reasons and motivations behind the CJEU's more guarded approach towards international human rights law in return law and policy. The conceivable explanations are manifold. These range from the desire to preserve the autonomy of EU law to the more extensive, if not exclusive reliance on the EU Charter instead of international human rights law instruments, namely the ECHR (see Peers, 2011; Ziegler, 2015; Tomuschat, 2016).

With regard to the former consideration, the EU Court's position in J.N. (C-6o1/15 PPU) is fairly illustrative, when the Explanations to the EU Charter have been used to confine the boundaries of ensuring necessary consistency between the Charter and the ECtHR jurisprudence: the need for such a consistency must be "without [...] adversely affecting the autonomy of Union law and $[\ldots]$ that of the Court of Justice of the European Union". ${ }^{36}$

36 CJEU, C-6o1/15 PPU, J.N. v. Staatssecretaris voor Veiligheid en Justitie, 15 February 2016, ECLI:EU:C:2016:84, para. 47 . 
As far as the gradual downplaying of the ECHR and the ECtHR case-law is concerned, empirical research demonstrates that after the entry into force of the Treaty of Lisbon in December 2009, the CJEU has examined and cited the Strasbourg case-law less frequently and extensively (Krommendijk, 2017). Several reasons are given for this, primarily on the basis of the observations of interviewed CJEU judges, former judges and référendaires as to the EU Court' readiness to cite the Strasbourg case-law. These include a growing awareness that both European apex courts are different as well as strategic reasons related to the wish to develop an autonomous interpretation of the Charter (Krommendijk, 2017). A few years ago the then president of the CJEU, Vassolios Skouris held that "the Court of Justice is not a human rights court: it is the Supreme Court of the European Union" (Besselink, 2014). As a result of this approach, cases are often solved on the basis of the primarily applicable secondary EU law (here: the Return Directive) and the CJEU's own pre-existing case-law, without relying on otherwise relevant standards of international human rights law; especially when the given piece of EU acquis stroke a certain balance between clashing fundamental rights claims or fundamental rights and State interests. Furthermore, the CJEU's distancing from human rights treaties other than the ECHR in developing the "general principles of EU law" can also be seen in its dismissal of the validity of UN monitoring treaty bodies' interpretations of human rights provisions in one case (OHCHR, 2011). In Grant, the EU Court rejected the weight of UN Human Rights Committee findings, stating that it "is not a judicial institution" and that its findings "have no binding force in law". ${ }^{37}$

However, one might also argue that the CJEU introduced the substance of international human rights law into its case-law via the EU Charter or by packaging certain human rights norms as general principles of EU law, without labelling them expressly as flowing from international human rights law. In other words: the EU Court was cognizant of the substance of various international human rights standards and engaged with the relevant human rights norms but when doing so, it labelled them as EU law and not as international human rights law. The reason for this "labelling" may be institutional or internal as well as a self-restraint not to be seen as interpreting international law norms for which other international courts or treaty bodies are competent. All this is paired with the EU Court's desire, following the French and continental tradition of constructing judgments, to keep the rulings as concise and minimalistic as possible (Krommendijk, 2017).

37 CJEU, C-249/96, Grant v. South West Trains Ltd, Judgment of 17 February 1998,
ECLI:EU:C:1998:63, para. 46 . AQ1: The cross-reference "Krommendijk, (2017)" is not been provided in the reference list. Please check and provide the same. AQ2: The cross-reference "ohchr, (2011)" is not been provided in the reference list. Please check and provide the same. 


\subsection{Final Thoughts}

This chapter attempted to understand the quite controversial perception of the role and place of international human rights law in the text of the Return Directive and in the CJEU case-law interpreting the Directive. The main question was - and to some extent, still remains to be - why different EU institutions (legislature v. judiciary) follow remarkably diverging treatment of international (human rights) law when shaping the EU return acquis.

Given that the Return Directive has been repeatedly and harshly criticised in academia and civil society for falling short of certain international human rights standards, the CJEU, using such hooks in the Directive, could have been in a position to address these alleged shortcomings in developing an interpretation of the Directive which fully takes into account and builds upon the sometimes higher standards and more developed safeguards offered by international law, especially the ECtHR jurisprudence. This silent ignorance of external norms is even more striking if compared to the CJEU case-law on asylum matters, which is much more open to international (refugee) law (see e.g. cases Bolbol, ${ }^{38}$ El Kott, ${ }^{39}$ Bundesrepublik Deutschland $v$ Y and Z; ${ }^{40}$ or Ministervoor Immigratie en Asiel v. $X, Y$ and $Z) .{ }^{41}$ In a similar vein, the CJEU's omission to adequately integrate the ECtHR case law in its reasoning in return-related cases is also surprising in mirrors of the EU Family Reunification Directive (2003/86/ EC), ${ }^{42}$ which also includes references to the ECHR (in recital (2)) as the Return Directive does. The EU Court clearly stated in the Chakroun ruling that relevant provisions of the Family Reunification Directive "must be interpreted in the light of the fundamental rights and, more particularly, in the light of the right to respect for family life enshrined in [...] the ECHR".43 (see also De Bruycker and Mananashvili, 2015).

38 CJEU, Case C-31/o9, Nawras Bolbol v. Bevándorlási és Állampolgársági Hivatal, Judgment of 17 June 2010, ECLI:EU:C:2010:351.

39 CJEU, C-364/11, Abed el Karem El Kott and Others v. Bevándorlási és Állampolgársági Hivatal, Judgment of 19 December 2012, ECLI:EU:C:2012:826.

40 CJEU, joined cases C-71/11 and C-99/11, Bundesrepublik Deutschland $v$. Y and Z, Judgment of 5 September 2012, ECLI:EU:C:2012:518.

41 CJEU, joined cases C-199/12, C-20o/12 and C-201/12, Minister voor Immigratie en Asiel v. X, Y and Z v. Minister voor Immigratie en Asiel, Judgment of 7 November 2013, ECLI:EU:C:2013:720. Emphasis added by the author - T.M.

42 Council Directive $2003 / 86 /$ EC of 22 September 2003 on the right to family reunification, OJ L 251, 3.10.2003, pp. 12-18.

43 CJEU, Case C-578/o8, Rhimou Chakrounv. Ministervan Buitenlandse Zaken, Judgment of 4 March 2010, EU:C:2010:117, para 44. 
This distancing from the Strasbourg Court-developed human rights standards is despite the fact that Article $5^{2}$ (3) of the Charter provides that the rights contained in the Charter which correspond to rights guaranteed by the ECHR are to have the same meaning and scope as those laid down by the ECHR and interpreted by the Strasbourg Court. Nonetheless, while acknowledging that fundamental rights recognised by the ECHR constitute general principles of EU law (Article 6(3) TEU) and the cardinal role of the ECHR and the ECtHR case-law as interpretive tools when adjudicating Charter rights, the CJEU has constantly underlined that the ECHR does not constitute, as long as the European Union has not acceded to it, a legal instrument which has been formally incorporated into EU law, therefore as such it is not legally binding on the EU.44

Here, at the intersectionality of laws (EU and international law) in the specific domain called "expulsion of aliens" (ILC) or "return of migrants in an irregular situation" (EU), one can clearly witness the CJEU's firm preference to one of the competing legal orders. As shown above, the EU Court has generally squeezed out other human rights norms of international origin when interpreting and further developing the edifice of EU return law. Nonetheless, one might still claim that although "the worlds are apart" from a purely formalistic perspective, substance-wise, when it comes to referring to and using by the CJEU quite a number of internationally protected human rights and principles by packaging them as EU law standards, "the worlds are very close". The ever-evolving jurisprudence of the EU Court will provide further responses and clarifications to the main question, whereas further empirical and legal sociological research still needs to be done to nuance our understanding of the diverging and converging approaches of the EU co-legislators and the judiciary towards international (human rights) law in return law and policy. The 1oth anniversary of the Return Directive's entry into force in December 2020 presents a great opportunity to put the CJEU return-related jurisprudence under scrutiny anew. The intellectual adventure has hereby begun.

\section{Acknolwedgement}

Legal research officer, European Union Agency for Fundamental Rights, Freedoms and Justice Department, Asylum, Migration and Borders Sector; adjunct

44 CJEU, C-571/10 Kamberaj, Judgment of 24 April 2012, ECLI:EU:C:2012:233, para. 62; CJEU, C-617/10, Åkerberg Fransson, Judgment of 26 February 2013, EU:C:2013:105, para. 44; CJEU, C-398/13 P, Inuit Tapiriit Kanatami and Others v. Commission, Judgment of 3 September 2015, EU:C:2015:535, para. 45. 
professor, Corvinus University of Budapest, Institute of International Studies (on leave).

The views expressed in this chapter are solely those of the author and its content does not necessarily represent the views or the position of the European Union Agency for Fundamental Rights. This article was supported by the János Bolyai Research Scholarship of the Hungarian Academy of Sciences.

\section{Bibliography}

Besselink, L. (2014), "The CJEU as the European 'Supreme Court': Setting Aside Citizens' Rights for EU Law Supremacy”, Verfassungsblog, 18 August 2014, (http://www. verfassungsblog.de/CJEU-european-supreme-court-setting-aside-citizens-rightseu-law-supremacy/)

Blanke, H-J, and S Mangiameli (2013), The Treaty on European Union (TEU): A Commentary, Berlin/Heidelberg: Springer.

European Commission (2017), Commission Recommendation of 27.09.2017 establishing a common "Return Handbook" to be used by Member States' competent authorities when carrying out return related tasks, $\mathrm{C}(2017) 6505$ final, Brussels, 27.09.2017, Annex ("EU Return Handbook")

Costello, C., and M. Foster (2016), "Non-refoulement as Custom and Jus Cogens? Putting the Prohibition to the Test", 46 Netherlands Yearbook of International Law, pp. 273-327.

De Bruycker, Ph., and S. Mananashvili (2015), "Audi alteram partem in immigration detention procedures, between the ECJ, the ECtHR and Member States: $G \& R^{\prime \prime}, 5^{2}$ Common Market Law Review, pp. 569-59o.

Farahat, A. (2015), "Enhancing Constitutional Justice by Using External References: The European Court of Human Rights' Reasoning on the Protection against Expulsion", 28 Leiden Journal of International Law, pp. 303-322.

Goodwin-Gill, G.S., and J. McAdam (2007), The Refugee in International Law, Oxford:Oxford University Press, third edition.

Hailbronner, K., and T. Daniel (2016), "Constitutional Framework and Principles for Interpretation", in K. Hailbronner and T. Daniel (eds), EU Immigration and Asylum Law. A Commentary, Munich/Oxford/Baden-Baden: C.H.Beck/Hart/Nomos, second edition, pp. 1-29.

Krommendijk, J. (2015), "The Use of the ECtHR Case Law by the Court of Justice after Lisbon. The View of Luxembourg Insiders" 22 Maastricht Journal of European and Comparative Law, pp. 812-835.

Lambert, H. (2007), The position of aliens in relation to the European Convention on Human Rights, Strasbourg: Council of Europe Publishing, (http://www.echr.coe.int/ LibraryDocs/DG2/HRFILES/DG2-EN-HRFILES-o8(2007).pdf). 
Lutz, F. (2010), The Negotiations on the Return Directive. Comments and Materials, Nijmegen: Wolf Legal Publishers.

Lutz, F., and S. Mananashvili (2016), "Return Directive 2008/115/EC", in K. Hailbronner and D. Thym (eds), EU Immigration and Asylum Law. A Commentary, Munich/Oxford/Baden-Baden: C.H.Beck/Hart/Nomos, second edition, pp. 658-763.

Maes, M., D. Vanheule, J. Wouters and M-C. Foblets (2011), "The international dimension of EU asylum and migration policy: framing the issues", in M. Maes, M-C. Foblets, Ph. De Bruycker, D. Vanheule and J. Wouters (eds), External Dimensions of EU Migration and Asylum Law and Policy/Dimensions Externes du Droit et de la Politique d'Immigration et d'Asile de l'UE, Bruxelles: Bruylant, pp. 9-6o.

Peers, S. (2011), "International law, human rights law, and EU asylum and migration policy", in M. Maes, M-C. Foblets, Ph. De Bruycker, D. Vanheule and J. Wouters (eds), External Dimensions of EU Migration and Asylum Law and Policy/Dimensions Externes du Droit et de la Politique d'Immigration et d'Asile de l'UE Bruxelles: Bruylant, pp. $63-88$.

Peers, S. (2016), EUJustice and Home Affairs Law. Volume I: EU Immigration and Asylum Law, Oxford: Oxford University Press, fourth edition, Sub-chapter 2.3 and Chapter 7 Rosas, A. (2014), "The Charter and Universal Human Rights Instruments", in S. Peers, T. Hervey. J. Kenner and A. Ward (eds.), The EUCharter of Fundamental Rights. A Commentary, Oxford/Portland: C.H.Beck/Hart/Nomos, pp. 1685-1701.

Regional Office for Europe of the United Nations High Commissioner of Human Rights (2011), The EU and International Human Rights Law, Brussels (http://www.europe. ohchr.org/Documents/Publications/EU_and_International_Law.pdf).

Taylor, A. (2015), The CJEU and its interaction with international law in the Qualification Directive: a calculated selectivity?, 12 February 2015 (http://www.asylumlawdatabase. eu/en/journal/cjeu-and-its-interaction-international-law-qualification-directivecalculated-selectivity).

Tomuschat, Ch. (2016), "The Relationship between EU Law and International Law in the Field of Human Rights", 35 Yearbook of European Law, pp. 604-620.

Wojnowska-Radzińska, J. (2015), The Right of an Alien to be Protected against Arbitrary Expulsion in International Law, Leiden: Brill.

Wouters, J., J. Odermatt and T. Ramopoulos (2012), "Worlds Apart? Comparing the Approaches of the European Court of Justice and the EU Legislature to International Law", Leuven Centre for Global Governance Studies, Working Paper No. 96 - August 2012 (https://ghum.kuleuven.be/ggs/publications/working_papers/2012/96woutersodermattramopoulos.pdf)

Ziegler, K. (2015), Autonomy: From Myth to Reality - or Hubris on a Tightrope? EU Law, Human Rights and International Law, University of Leicester School of Law Research Paper No. 15-25 (http://ssrn.com/abstract=2665725) 